\title{
Limitations and possibilities in university management performed by nursing managers*
}

\author{
Limites e possibilidades na gestão universitária realizada por enfermeiros gestores \\ Límites y posibilidades en la gestión universitaria realizada por enfermeros gestores
}

How to cite this article:

Cunha KS, Erdmann AL, Andrade SR, Kahl C, Salum MEG, Fabrizzio GC. Limitations and possibilities in university management performed by nursing managers. Rev Esc Enferm USP. 2020;54:e03556. DOI: http://dx.doi.org/10.1590/S1980-220X2018044303556

\section{Kamylla Santos da Cunha ${ }^{1}$ \\ Alacoque Lorenzini Erdmann² \\ Selma Regina de Andrade ${ }^{2}$ \\ Carolina Kahl ${ }^{1}$ \\ Maria Eduarda Grams Salum ${ }^{1}$ \\ Greici Capellari Fabrizzio ${ }^{1}$}

* Extracted from the dissertation: "Gestão universitária: significado para enfermeiros docentes do Curso de Graduação em

Enfermagem de uma universidade pública”,

Programa de Pós-Graduação em Enfermagem

Universidade Federal de Santa Catarina, 2016.

${ }^{1}$ Universidade Federal de Santa

Catarina, Programa de Pós-graduação em

Enfermagem, Florianópolis, SC, Brazil.

${ }^{2}$ Universidade Federal de Santa Catarina,

Departamento de Enfermagem,

Florianópolis, SC, Brazil.

\begin{abstract}
Objective: Understand limitations and possibilities in university management performed by nursing managers of the undergraduate nursing course of a public university. Method: A qualitative study with theoretical and methodological framework anchored in the Grounded Theory. Data collection took place between May and September 2016, and the studied scenario was the Nursing Department of a public university in southern Brazil. Results: The entrepreneurial profile and the leadership in interpersonal relations were highlighted among the possibilities, in addition to the co-responsibility in raising public resources to solve the university educational demands; as limitations, the scarcity of financial resources and the high demand for bureaucratic activities which have repercussions on the slowness of university public management processes. Conclusion: The nursing manager experiences limitations through their actions and interactions with people, and recognizes possibilities in the structure and processes of coordinating issues of collective interest in the university educational context.
\end{abstract}

\section{DESCRIPTORS}

Faculty, Nursing; Education, Nursing; Universities; Organization and Administration. 


\section{INTRODUCTION}

Public universities are educational institutions which influence and are influenced by society in their structures and processes. They mainly differ from other institutions in the inseparability of teaching, research and extension. The research developed in this context subsidizes teaching updating it, which returns to society through university extension ${ }^{(1)}$

University management occurs through actions and administrative interactions to operate the institution, mostly being developed by university professors, even if they do not have appropriate training for this purpose. Such activity is provided through election by faculty, students and administrative technicians, who mainly consider relational aspects and managerial competences among the criteria for the position to face the challenges in this scenario $^{(2-3)}$.

In this context, nursing professors as well as other professors in other educational areas extend their responsibilities in the classroom, research and technological and human development to educational management actions, promoting different conditions for the university to fulfill its educational and social mission ${ }^{(4)}$. However, international studies have shown an intention of teaching nurses to leave the university environment due to the increase in workloads deriving from the multiple activities developed in which they are challenged to balance teaching activities, research and scholarships, tutoring, practice and clinical supervision of students, and institutional administrative functions, resulting in a high level of emotional exhaustion and dissatisfaction ${ }^{(5-6)}$.

The multiple roles of the university nursing manager can trigger internal and external conflicts by developing administrative processes using a large part of their time for the final graduation activity ${ }^{(7)}$. The university management activities performed by the nursing manager require knowledge and recognition of limitations, which would cause slowness in the educational processes, however creating possibilities and opportunities to overcome such obstacles.

Considering that university management activities are important means to reach the university's ultimate goal of training, and that these processes require efficiency and effectiveness to overcome challenges, the objective of this research was to understand the limitations and possibilities of university management performed by nursing managers of the undergraduate nursing course of a public university.

\section{METHOD}

\section{Study Design}

A qualitative study with its theoretical and methodological framework based on the Grounded Theory (GT), Straussian version, which seeks to understand social phenomena from the meanings of relationships and interactions between people in a given context ${ }^{(8)}$. The method is oriented through a systematic analysis of data, so that structure and process are integrated and enable creating a theory ${ }^{(8)}$.

\section{SCENARIO}

The study scenario was the Nursing Department of a public university, and the theoretical sample consisted of 19 university teaching nurses divided into two sample groups. The first sample group was intentionally chosen, consisting of faculty nurses who held departmental leadership activities, and the second group consisted of coordinators or former course coordinators and/or faculty nurses in other management positions at the university.

\section{SeleCtion CRITERIA}

Inclusion criteria for both groups were: university faculty nurses, working in the Department of Nursing with exclusive dedication, active or retired, occupying university management positions (chiefs or former chiefs; coordinators or former course coordinators) and teaching nurses in other university management positions. The exclusion criteria for both groups were limited to: managing professors or former teaching managers away from work for any reasons during the data collection period and substitute professors.

\section{DATA COLLECTION}

Data collection took place between May and September 2016. Participants were invited to take part in the survey via e-mail, and the interviews were previously scheduled and held at the participant's own discretion. Open and individual interviews were performed, recorded using a digital voice audio recorder, with an average duration of 40 minutes. Data collection and analysis occurred simultaneously through constant comparative data analysis ${ }^{(8)}$.

The guiding question used in the first sample group was: "How do you describe university management performed by nursing managers in the nursing department?", leading to the hypothesis that 'departmental management is directly related to university institutional management', leading to the second sample group where the guiding questions were "How do you describe university management performed by managing professors in the Nursing Department of this university" and "How do you experience the relationship and interaction between the micromanagement of the Nursing course and the university macromanagement?".

\section{DATA ANALYSIS AND PROCESSING}

NVivo ${ }^{\circledR}$ software was used to organize data during the comparative analysis and data coding phase. The analysis process followed open coding, axial coding and integration ${ }^{(8)}$. In open coding, data were analyzed line by line in order to identify each incident. Codes were generated which promoted elaboration of the concepts after grouping. In the axial coding, the data were grouped in order to obtain a clearer and more complete explanation of the phenomenon, relating categories to their subcategories through a systematic analytical process of comparison and connection guided by the three-component paradigmatic model of the updated version of this strand ${ }^{(8)}$. The "Condition" answers questions about why, when, and how a particular phenomenon happens, designated through an action; "Action-interaction" 
is the response expressed to events or situations as well as people moving by way of the meaning; and "Consequence" expresses expected or actual outcomes and results ${ }^{(8)}$. Finally, the categories and subcategories found were compared, analyzed and refined in the integration phase ${ }^{(8)}$, thus emerging the phenomenon entitled "Articulating complex collectives through university management for qualified training of new nurses". Theoretical data saturation was achieved when the incidents no longer added data which developed other properties of the concepts or elicited new theoretical insights into the phenomenon.

It was decided to broaden and deepen the discussion of the "action-interaction" component inherent to the paradigmatic model proposed by the method, considering that it represents the movements and efforts of the university manager nurse which promote an important relationship with understanding the central phenomenon.

Memos and diagrams were also elaborated during the data analysis ${ }^{(8)}$, which concern the researchers' records and insights in the theory construction process.

\section{ETHICAL ASPECTS}

The ethical precepts of Resolution 466/2012 of the National Health Council were followed. The project was approved by the Ethics Committee on Research with Human Beings of the Universidade Federal de Santa Catarina, under Opinion no. 1.468.660/2016. The letter I was followed by the number corresponding to the order of the interviews to designate them $(\mathrm{I} 1, \mathrm{I} 2 \ldots)$ in order to ensure confidentiality and anonymity of the participants, and then indication of the sample group - first group (G1) and second group (G2) - as follows: (I1G1); (I1G2).

\section{RESULTS}

The data showed that the resolution of educational demands provides knowledge of the processes and structure of university management, their limitations and possibilities, which enable appropriate decision-making for each moment, and favor a critical look associated with proposals for management improvements. In this scenario, there is a need for the manager to recognize themself as an institution, knowing that in addition to practical, legal and political aspects, as well as the correlation of forces in the ideological context, making a conjunctural reading that will require political-pedagogical positions at certain times within the institutional context.

I think there are several advantages in university management. To know beyond your classroom microspace and understand how this space is closely related to the larger structure of the university, to be able to understand these links and how these actions are interdependent (...) to understand this dynamics of articulated work (I6G1).

We are talking about a federal public university management that has differences depending on the positions, the responsibility of the positions. Many of the multiple positions I held during my academic life had different demands, different roles, because there is always the university statute which is the advisor for each position, similar to the university's bylaws and statute, which is the letter that guides the management process and activities within the university, what you have to govern and what you don't have (I9G2).

The logic of public educational institutions was highlighted, and together with this the bureaucracy that generates slowness in the processes, whether they are pedagogical or structural. On the other hand, there is also the understanding that these procedures are necessary for protecting the institution because it is a public service. Although the handling of university management actions is inherent to managing professors, they in turn emphasize the overload of technical functions arising from the high demand of bureaucratic issues which could be performed with the help of administrative technical professionals.

University management and educational management are always one function to another at all times. To get the undergraduate courses to work you have a whole structure in place, you have the backstage to make the course work (...). In this process there are bureaucratic limitations in order to be able to buy a table, chair, computer, to get qualified technical-administrative staff who would know and support the management, especially financial limitations in the fundraising management, all demanding a lot of effort from the managing professor (I11G2).

When I took over as head of the department, I had no idea of this bureaucratic and time consuming part of the university to get things related to infrastructure, I had no idea (I12G2).

The managing professor also has the co-responsibility of the fundraising for the teaching structure in their attributions which starts from a public notice of funding agencies, to which the professors submit their research projects. Projects are required to meet all the requirements of the announcement, while professors are required to have academic productivity.

When we needed to raise funds, one of the strategies was to resort to official projects from the university foundations and after approval we could pay for outsourced services (...) we were able to guarantee staff who could handle needs as a translator for international projects, simultaneous translations to receive international guests, all of which gave a great deal of strain, but also brought a sense of gratification (I9G2).

We organized ourselves, prepared a well-structured project, answering all the requirements requested in the grant agency's edict, such as academic productivity. We were very thorough and after all these efforts we were contemplated. At the time it was a necessity for the simulated practice labs course because, before, we went with the almost "raw" students to practice, after building the lab we have all simulated work where we do the activities on a dummy; it strengthens the issue of student ego, student confidence and also gives the teacher more confidence (I11G2).

Given this context, the management professor's handling of interpersonal relationships is emphasized, which involve expectations, needs, desires, priorities, and visions, whether of professors or students. The teaching professor is required to understand the different roles people play in an institution, the ability to work with people's subjectivity 
and differences, their thoughts and desires. Thus, the manager, as the leader, is responsible for the collective, even in situations where it is impossible to consult other professors and students, because the management mechanism supports them for this.

Decisions are always collective, and it is up to the boss to execute those decisions (...). Eventually, of course, there is always a perspective that you have an independent decision from the collegiate, which comes with the representative office, for example. So outside of the university, at a national meeting, an international meeting, with other peers, I am obligated as the chief to answer for the collective, although I have not always consulted with them. But the management process, the management mechanism you impose also gives you the credentials for it, because you only do this as you know the group, who you know and who you rely on, what the expectations are. As long as you have symbiosis with the group, you can make commitments because you know you have identification (I6G1).

One quality of leadership that I value the most is respecting diversity, people and defending their ideas, but respecting other ideas (...). Of course we experienced conflicts, but I think the important thing is to gain credibility in management by respecting differences and democracy if you decide; the times I lost votes and I respected the decisions; the times I won, I ensured that the people who lost respected the positions (I3G1).

The participants also showed that most professors have an entrepreneurial profile, knowledge of issues related to nursing education, which gives them autonomy to help the department head in subgroups of activities distributed between laboratory, phase coordination, internship coordination, extension coordination, and research coordination.

There is a structure and definition of roles. We have a group that works more with the laboratory, we have the coordinators of the phases which help us in organizing teaching, the internship coordinator, we have this autonomy to assist the leadership in organizing the practical activities in the fields, the extension coordinator who helps in supervising the extension hours of the professors, the research coordinator in relation to the research. We have a group that supports the boss; the boss doesn't work alone, nor should they (I4G1).

My choice was always to debate the issues in the collegiate with the other professors and students, to accept and forward the deliberations that had been made by the group, elected and democratically decided. So, regardless of whether I had a majority or not in that, I was there to represent the interests of a group, everyone contributed, they always make great discussions (...) so I referred what the collegiate decided, what the majority decided (I9G2).

In summary, the data revealed the scarcity of resources and the bureaucracy and slowness in the processes of university public management as limitations; and the entrepreneurial profile and leadership in interpersonal relations for the dynamics of the processes as possibilities, adding efforts in the co-responsibility of fundraising to solve the university educational demands. This appreciation led to proposing a diagram of limitations and possibilities in university management performed by nursing managers, as shown in Figure 1.

\section{Actions and interactions in university management}

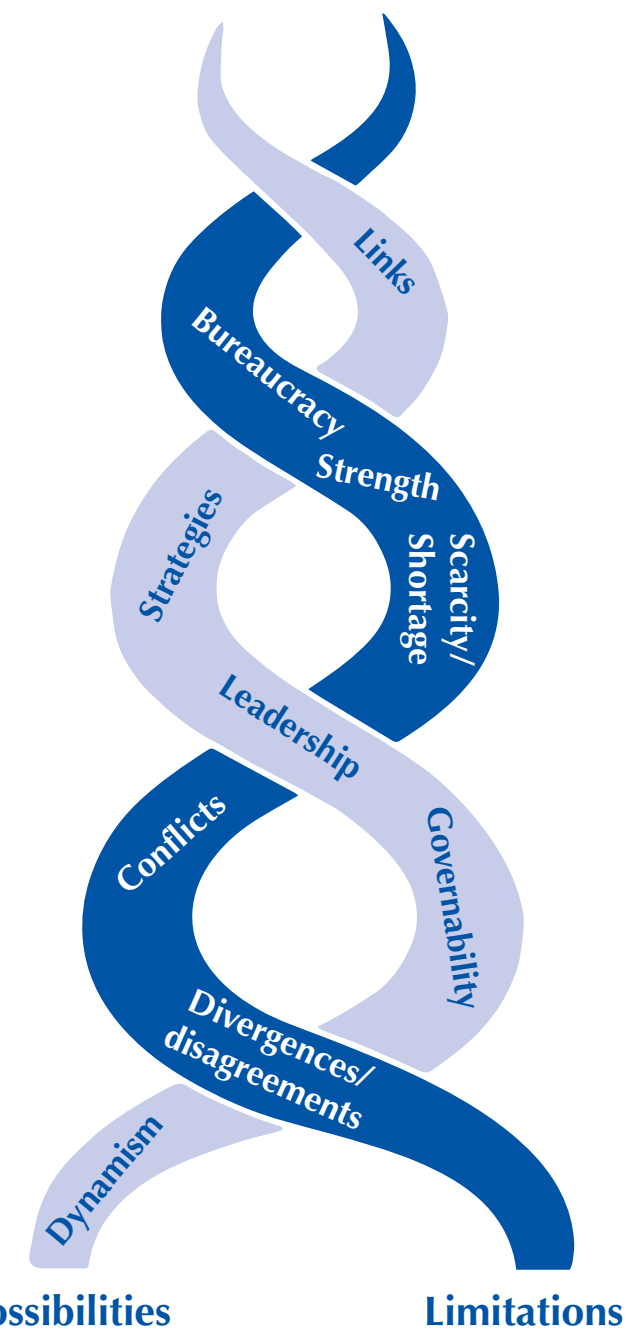

Figure 1 - Diagram: limitations and possibilities in university management performed by nursing managers.

\section{DISCUSSION}

The data generally showed that nursing managers know limitations in practice and recognize possibilities of their actions in coordinating issues of collective interest through their actions and interactions with people, structure and processes in the university educational context.

Due to the fact that this is a public organization, bureaucratic obstacles such as rules, regulations and controls contained in management processes for compliance with the laws stood out as limitations. A study on innovations in Brazilian public management highlights unfavorable bureaucratic barriers in creating new management ideas. Bureaucracy, as a management model, allows doing only what is foreseen in laws and internal norms, limiting creativity and causing processes to be slow and sluggish ${ }^{(9)}$. 
Another aspect evidenced as a limitation by the nurse manager when performing university management was the scarcity of resources; an issue present in the public service of higher education. That said, an expansion of management activities was noted which add more functions to the position and makes the business even more complex, the nursing manager's search for funding agencies to acquire financial, material and human resources to meet educational needs ${ }^{(10)}$. Still, governance efforts and research time are indispensable for robust academic production which enables them to be contemplated by funded projects ${ }^{(11)}$.

In these efforts, a study carried out with nine senior university administration managers problematizes the removal of managers from their teaching area within the classroom due to the high workload that the university management position has; in particular, the hourly workload destined to bureaucratic issues and resource mobilization which require greater dedication and time from the manager ${ }^{(12)}$.

The data from this research present the entrepreneurial profile competencies and the leadership of the nursing manager as possibilities in order to manage such barriers and circumvent the slowness in the fluidity of the pedagogical and structural processes in the university. Similarly, a study conducted at US universities highlighted positive aspects concerning institutional leadership, subgroup support through departmental division, autonomy and strengthening interpersonal relations in university management ${ }^{(13)}$, thereby contributing to the co-responsibility in university management processes.

Emphasizing the magnitude of the nursing manager's interpersonal relationships, a study conducted with coordinators from 14 undergraduate nursing courses in Belo Horizonte, Minas Gerais state, showed among its results the importance of good interpersonal relationships and leadership skills in relation to other professors and administrative staff for the effectiveness of university management ${ }^{(14)}$. Establishing interpersonal relationships in university management can be understood as a required political competence of the nursing manager, characterized by their ability to understand the organizational culture, dialogue and articulation between peers, making external partnerships to supply needs, resources and exchange of experiences ${ }^{(15)}$.

In addition, another issue of great magnitude in exercising university management positions is to conduct decision-making by the collective as a leader. Ethics is challenging in collective decision-making given the difficulty of the manager to thoroughly evaluate the possible consequences that their action may cause in the various contexts of the university, in addition to exceeding the expectations of others, who expect decisions to coincide with their opinions ${ }^{(16)}$, reinforcing that management positions require practical administrative, personal and relational skills, and that many of these are strengthened with the exercise of functions and maturity acquired over time ${ }^{(17)}$.

\section{CONCLUSION}

The findings showed that nursing managers are exposed to limitations through actions and interactions in the university educational environment related to the high demand for bureaucratic activities and the scarcity of public resources, which affect the length of processes and the maintenance of university infrastructure.

Thus, this study recognized possibilities for the role of the nursing manager, with emphasis on their entrepreneurial profile and leadership in interpersonal relationships, which gives them autonomy and political-pedagogical position in collective decisions. On the other hand, the limitations related to the university educational demands experienced by the nursing managers require co-responsibility in acquiring public resources necessary to overcome them.

\section{RESUMO}

Objetivo: Compreender limites e possibilidades na gestão universitária realizada por enfermeiros gestores do curso de graduação em enfermagem de uma universidade pública. Método: Pesquisa qualitativa, com referencial teórico-metodológico ancorado na Teoria Fundamentada nos Dados. A coleta de dados ocorreu entre maio e setembro de 2016, e o cenário estudado foi o Departamento de Enfermagem de uma universidade pública da região Sul do Brasil. Resultados: Dentre as possibilidades, destacaram-se o perfil empreendedor e a liderança nas relações interpessoais, além da corresponsabilização na captação de recursos públicos para resolução das demandas educacionais universitárias; como limites, a escassez de recursos financeiros e a elevada demanda de atividades burocráticas que repercutem em morosidade dos processos de gestão pública universitária. Conclusão: $\mathrm{O}$ enfermeiro gestor, por meio das suas ações e interações com as pessoas, vivencia limites e reconhece possibilidades na estrutura e nos processos da coordenação de assuntos de interesse coletivo no contexto educacional universitário.

\section{DESCRITORES}

Docente de Enfermagem; Educação em Enfermagem; Universidades; Organização e Administração.

\section{RESUMEN}

Objetivo: Comprender los límites y posibilidades en la gestión universitaria realizada por enfermeros gestores de la carrera de licenciado en enfermería de una universidad pública. Método: Investigación cualitativa, con marco de referencia teórico metodológico anclado en la Teoría Fundamentada en los Datos. La recolección de datos ocurrió entre mayo y septiembre de 2016, y el escenario estudiado fue el Departamento de Enfermería de una universidad pública de la región Sur de Brasil. Resultados: Entre las posibilidades, se destacaron el perfil emprendedor y el liderazgo en las relaciones interpersonales, además de la corresponsabilización en la captación de recursos públicos para resolución de las demandas educativas universitarias; como límites, la escasez de recursos financieros y la elevada demanda de actividades burocráticas que repercuten en morosidad de los procesos de gestión pública universitaria. Conclusión: El enfermero gestor, mediante sus acciones e interacciones con las personas, enfrenta límites y reconoce posibilidades en la estructura y los procesos de la coordinación de temas de interés colectivo en el marco educativo universitario.

Docentes de Enfermería; Educación en Enfermería; Universidades; Organización y Administración. 


\section{REFERENCES}

1. Gonçalves NG. Indissociabilidade entre ensino, pesquisa e extensão: um princípio necessário. Perspectiva. 2015;33(3):1229-56. DOI: https://doi.org/10.5007/2175-795X.2015v33n3p1229

2. Adriano BM, Ramos F. Liderança universitária: uma revisão das publicações nacionais e estrangeiras sobre o tema. Navus [Internet]. 2015 [citado 2018 jul 23];5(4):44-64. Disponível em: http://navus.sc.senac.br/index.php/navus/article/view/275

3. Wilhelm FA, Zanelli JC. Características das situações estressantes em gestores universitários no contexto do trabalho. Estud Pesq Psicol [Internet]. 2013 [citado 2017 jul. 28];13(2):704-23. Disponível em: http://www.e-publicacoes.uerj.br/index.php/revispsi/article/ view/8432/7327

4. Meyer JRV. A prática da administração universitária: contribuições para a teoria. Rev Univ Debate. 2014;2(1):12-26. DOI: http://doi. org/10.7213/univ.debate.02.001.AO01

5. Roughton SE. Nursing faculty characteristics and perceptions predicting intent to leave. Nurs Educ Perspect. 2013;34(4):217-25.

6. Yedidia MJ, Chou J, Brownlee S, Flynn L, Tanner CA. Association of faculty perceptions of work-life with emotional exhaustion and intent to leave academic nursing: report on a national survey of nurse faculty. J Nurs Educ. 2014;53(10):569-79. DOI: http://dx.doi. org/.3928/01484834-20140922-03

7. Candela L, Gutierrez AP, Keating S. What predicts nurse faculty members' intent to stay in the academic organization? A structural equation model of a national survey of nursing faculty. Nurse Educ Today. 2015;35(4):580-9. DOI: https://doi.org/10.1016/j.nedt.2014.12.018

8. Corbin J, Strauss A. Basics of qualitative research: techniques and procedures for developing Grounded Theory. Los Angeles: Sage; 2015.

9. Brandao SM, Bruno-Faria MF. Inovação no setor público: análise da produção científica em periódicos nacionais e internacionais da área de administração. Rev Adm Pública. 2013;47(1):227-48. DOI: http://dx.doi.org/10.1590/S0034-76122013000100010

10. Barbosa MAC, Mendonça JRC. O professor-gestor e as políticas institucionais para a formação de professores de ensino superior para a gestão universitária. Econ Gestão. 2016; 16(42):61-88. DOI: https://doi.org/10.5752/P.1984-6606.2016v16n42p61

11. Gomes OF, Gomide TR, Gomes MAN, Araujo DC, Martins S, Faroni W. Sentidos e implicações da gestão universitária para gestores universitários. Rev GUAL. 2013;6(4):234-55. DOI: http://dx.doi.org/10.5007/1983-4535.2013v6n4p234

12. Gomide TR, Gomes MANG, Araujo DC, Martins S, Faroni W. Sentidos e implicações da gestão universitária para gestores universitários. Revista Gestão Universitária na América Latina. 2013;6(4):234-55. DOI: https://doi.org/10.5007/1983-4535.2013v6n4p234

13. Emory J, Lee P, Miller MT, Kippenbrock T, Rosen C. Academic nursing administrators' workplace satisfaction and intent to stay. Nurs Outlook. 2016;1(1):1-7. DOI: http://dx.doi.org/10.1016/j.outlook.2016.07.003

14. Seabra ALC, Paiva KCM, Luz TR. Managerial competences of coordinators of undergraduate nursing courses. Rev Bras Enferm. 2015;68(5):890-8. DOI: http://dx.doi.org/10.1590/0034-7167.2015680518i

15. Salles MASD, Villardi BQ. O desenvolvimento de competências gerenciais na prática dos gestores no contexto de uma IFES centenária. Rev Serv Público. 2017;68(2):467-92. DOI: https://doi.org/10.21874/rsp.v68i2.795

16. Santos L, Bronnemann MR. Desafios da gestão em instituições de ensino superior: um estudo de caso a partir da percepção de diretores de centro de uma IES pública do sul do Brasil. Rev Gestão Univ América Latina. 2013;6(1):1-21. DOI: http://dx.doi.org/10.5007/1983$4535.2013 v 6 n 1 p 1$

17. Wilhelm FA, Zanelli JC. Características das situações estressantes em gestores universitários no contexto do trabalho. Est Pesq Psicol. 2013;13(2):704-23. DOI: https://doi.org/10.12957/epp.2013.8432 